\title{
Pola penyediaan dan rantai pasok pakan serat pada musim kemarau di peternakan rakyat sapi perah, Lembang, Kabupaten Bandung Barat
}

\author{
Atikah Nur Hamidah ${ }^{1, *}$ Norma Nuraina ${ }^{1}$, Despal ${ }^{2}$, Epi Taufik ${ }^{1}$ \\ ${ }^{1}$ Departemen Ilmu Produksi dan Teknologi Peternakan, Fakultas Peternakan, IPB University, Bogor, 16680 \\ ${ }^{2}$ Departemen Ilmu Nutrisi dan Teknologi Pakan, Fakultas Peternakan, IPB University, Bogor, 16680 \\ *Correspondence: atikahhamidah26@gmail.com; Telp.: +62-8138-039-8901
}

Received: May 22 ${ }^{\text {th }}, 2020$; Accepted: February 26 ${ }^{\text {th }}, 2021$; Published online: March 22 ${ }^{\text {th }}, 2021$

\section{Abstrak}

Tujuan: Penelitian ini bertujuan untuk mengetahui sumber pakan serat yang biasanya digunakan, menganalisis kegiatan penyediaan pakan serat di peternakan sapi perah rakyat pada musim kemarau, dan mengetahui rantai pasok pakan serat.

Metode: Penelitian ini dilakukan di peternakan sapi perah rakyat Kecamatan Lembang, Kabupaten Bandung Barat. Wawancara dilakukan kepada 50 peternak menggunakan teknik purposive sampling untuk memperoleh informasi pola penyediaan dan rantai pasok pakan serat. Pengambilan sampel berupa pakan serat yang digunakan di peternakan tersebut menggunakan teknik pengambilan acak sederhana. Data yang diperoleh dianalisis secara deskriptif. Data berupa kandungan nutrien pakan serat, pola penyediaan yang dilakukan pada musim kemarau, dan peta rantai pasok pakan serat.

Hasil: Hasil penelitian menunjukkan bahwa pakan serat yang diberikan kepada sapi perah berupa rumput budidaya, tumbuhan alam, legum, dan limbah tanaman yang seluruhnya berasal dari daerah sekitar $(\leq 30 \mathrm{~km})$ dengan kandungan nutrien yang bervariasi. Terdapat 16 pola penyediaan pakan serat pada musim kemarau dengan pola terbanyak yaitu kombinasi mengarit di lahan sendiri dan membeli. Berdasarkan perhitungan RFV, legum dan limbah sayuran memiliki kualitas yang baik. Rantai pasok pakan serat relatif pendek (1-4 aktor) karena pakan serat yang digunakan umumnya dalam bentuk segar dan tanpa diolah.

Kesimpulan: Dapat disimpulkan bahwa sumber pakan serat yang digunakan yaitu rumput budidaya, tumbuhan alam, legum, dan limbah tanaman. Terdapat 16 pola penyediaan pada musim kemarau. Rantai pasok pakan serat memiliki rantai yang relatif pendek.

Kata Kunci: Kandungan nutrien; Pakan serat; Pola penyediaan; Rantai pasok

\section{Abstract}

Objective: This study aimed to explore and understand the source of fiber feed that is commonly used, and analyze the activities of fiber feed provision in dairy farms during the dry season, and investigate the fiber feed supply chain.

Methods: This research was conducted on rural dairy farms in the Sub-district of Lembang located in West Bandung District. The data was collected by adopting an interview method with 50 farmers implements a purposive sampling technique to gather information regarding 
the provision pattern, supply chain of respective fibre feed. Samples of fiber feed in the dairy farms were taken using a simple random sampling technique. The data acquired is analyzed using descriptive analysis; these data consist of nutrient content of the fiber feed, provision pattern during the dry season, and the supply chain map of those fiber feed provisions.

Results: The result reveals that the fiber feed that has been given to the dairy cows was cultivated grass, natural grass, legumes, and plant residue that entirely supplied from neighborhood area $(\leq 30 \mathrm{~km})$, which has different nutrient content. There are 16 provision patterns of fibre feed in the dry season, the vast majority of provision pattern was the combination of foraging from the farmer's land and feed purchasing. By referring to the RFV calculations, legumes and vegetable waste have good quality. The fibre feed supply chain is relatively short, which is about (1-4 actors) due to its freshness and required no processing.

Conclusions: In conclusions, the fibre feed that has been given to the dairy cows was cultivated grass, natural grass, legumes, and plant residue. There are 16 provision patterns of fibre feed in the dry season. The fibre feed supply chain is relatively short.

Keywords: Fiber feed; Nutrient content; Provision pattern; Supply chain

\section{PENDAHULUAN}

Pakan sumber serat berperan penting sebagai pakan basal sapi perah yang menyediakan nutrisi dalam menentukan produksi susu [1]. Pakan serat dapat berasal dari rumput budidaya, berbagai jenis leguminosa, rumput liar [2], dan hasil ikutan pertanian [3]. Serat kasar dibutuhkan dalam pakan sapi perah agar rumennya berfungsi dengan normal. Saat mengonsumsi pakan serat, sapi akan memproduksi air liur yang bermanfaat untuk menetralkan $\mathrm{pH}$ rumen sehingga dapat terhindar dari asidosis rumen [4]. Hal ini menunjukkan bahwa pakan serat memang sangat dibutuhkan oleh sapi perah. Serat kasar yang tinggi dalam pakan dapat menurunkan kecernaan pakan sehingga perlu diperhatikan kandungan selulosa, hemiselulosa, dan lignin yang terkandung di dalamnya [5]. Jenis pakan sumber serat yang diberikan kepada ternak ruminansia diharapkan mudah dicerna dan memiliki kualitas yang baik [6].

Faktor pembatas utama dalam penyediaan pakan serat yang berkualitas dan berkelanjutan di Indonesia yaitu iklim dan lahan yang terbatas. Faktor pembatas tersebut mengharuskan peternak mengumpulkan atau membeli limbah pertanian untuk sumber pakan serat [7]. Ketersediaan lahan untuk budidaya hijauan dan tingginya biaya pakan merupakan permasalahan yang dihadapi dalam usaha sapi perah [8]. Persediaan pakan serat untuk pakan yang cukup secara kualitas dan kuantitas merupakan hambatan utama dalam bidang peternakan ruminansia [9].

Lembang merupakan kecamatan yang berada di Kabupaten Bandung Barat yang menjadi salah satu kawasan sentra peternakan sapi perah di Indonesia. Peternak Lembang melakukan kegiatan penyediaan pakan serat secara individu. Pakan merupakan biaya yang terbesar di antara seluruh biaya produksi [8] sehingga sangat berpengaruh terhadap pendapatan usaha tersebut. Apalagi pakan serat memiliki persentase paling besar dalam pemberian pakan untuk sapi perah sedangkan peternak mengeluarkan biaya yang beragam untuk memperoleh pakan tersebut.

Penelitian terdahulu telah dilakukan oleh peneliti lain untuk mengetahui pola penyediaan pakan serat di beberapa daerah di Indonesia. Seperti halnya di daerah Sidoharjo, sebagian besar melakukan penyediaan pakan serat dengan cut and curry yang memanfaatkan berbagai jenis pakan serat seperti rumput, legum, dan tumbuhan alam [10]. Penelitian lain juga menyebutkan pola pemberian pakan serat di daerah Dompu Nusa Tenggara Barat dengan cara cut and curry atau digembalakan. Pada musim hujan, biasanya peternak memanfaatkan rumput, legum, dan gulma sedangkan pada musim kemarau sebagian besar petani bergantung pada padang rumput, legum, limbah pertanian, dan sisa tanaman [11]. 
Kedua penelitian tersebut menunjukkan adanya perbedaan pola penyediaan dan jenis pakan serat yang digunakan oleh peternak tergantung dari ketersediaan hijauan di daerah tersebut. Penelitian tersebut juga menunjukkan bahwa pada musim kemarau, memungkinkan peternak memanfaatkan jenis pakan serat yang lebih banyak dibandingkan pada musim hujan.

Sumber daya manusia yang terlibat dalam kegiatan penyediaan pakan serat tentunya terdapat aliran rantai pasok dalam kegiatan tersebut. Rantai pasok merupakan suatu jalur aliran sumber daya fisik dari titik sumber hingga sampai ke titik destinasi [12]. Penelitian tentang rantai pasok oleh peneliti lain telah dilakukan di Uni Eropa. Penelitian tersebut menunjukkan bahwa rantai pasok pakan sangat berdampak pada harga produk hasil ternak di negara tersebut. Panjangnya rantai pasok pakan tentunya akan membuat produk ternak semakin tinggi karena dipengaruhi oleh biaya produksi [13]. Sebagian besar peternakan di Indonesia masih melakukan penyediaan pakan serat secara individu. Hal tersebut memungkinkan terdapat perbedaan aliran pakan serat tergantung cara peternak melakukan penyediaannya. Kebanyakan peternak di Lembang membeli pakan serat berupa jerami dengan harga yang cukup tinggi namun tidak mengetahui kandungan nutrien yang terkandung di dalamnya. Oleh karena itu perlu mengetahui aliran rantai pasok pakan serat di daerah tersebut sehingga manajemen rantai pasok memungkinkan untuk diterapkan.

Penelitian ini bertujuan untuk mengetahui sumber pakan serat yang biasanya digunakan, menganalisis kegiatan penyediaan pakan serat pada musim kemarau, dan mengetahui rantai pasok pakan serat di peternakan sapi perah Lembang.

\section{MATERI DAN METODE}

\section{Pengumpulan Data}

Metode observasi dan wawancara dilakukan dalam pengumpulan data pada penelitian ini yang dilaksanakan pada bulan Oktober hingga November 2020. Bulan November memang memasuki awal musim hujan, namun dalam budidaya pakan serat membutuhkan waktu setidaknya 2 hingga 3 bulan dalam pemanenannya sehingga pada bulan tersebut peternak masih terkena dampak dari musim kemarau.

Komponen yang diamati dalam observasi yaitu kondisi peternakan, kegiatan atau aktivitas peternak dalam melakukan penyediaan pakan serat, dan pelaku yang terlibat dalam kegiatan penyediaan tersebut.

Wawancara dilakukan kepada 50 peternak dengan menggunakan metode bertanya langsung kepada informan. Pengambilan jumlah informan tersebut telah disesuaikan dengan kebutuhan penelitian dan pemilihan informan menggunakan metode purposive sampling berdasarkan kriteria yang disesuaikan dengan tujuan penelitian [14]. Kriteria pemilihan informan yaitu peternak sapi perah di Kecamatan Lembang dan peternak yang melakukan penyediaan pakan sumber serat. Data yang dikumpulkan meliputi cara penyediaan pakan serat, biaya yang dikeluarkan dalam penyediaan tersebut, jenis alat transportasi yang digunakan, dan jumlah pakan serat yang diperoleh setiap melakukan kegiatan penyediaan tersebut. Wawancara juga dilakukan kepada pelaku usaha yang terlibat dalam kegiatan penyediaan pakan serat sehingga didapatkan pergerakan aliran pakan tersebut sampai ke peternak.

\section{Analisis Kandungan Nutrien}

Sampel dalam penelitian ini berupa pakan sumber serat yang digunakan dalam penyediaan pakan di peternakan tersebut. Pengambilan sampel pakan serat menggunakan teknik pengambilan acak sederhana. Sampel yang telah diambil, diletakkan pada wadah yang tidak mempengaruhi keadaan sampel. Kemudian sampel diberi label dengan keterangan berisi tanggal penerimaan, tanggal pengambilan sampel, asal peternakan, berat basah, dan keterangan lain yang dibutuhkan. Sampel yang diambil dikeluarkan dari tempat penyimpanan. Sampel dikeringkan terlebih dahulu di bawah sinar matahari selama 2-3 hari kemudian sampel dipanaskan dengan oven $60^{\circ} \mathrm{C}$ sebelum sampel dihaluskan 
menggunakan mesin giling. Sampel yang telah halus kemudian dianalisis.

Pengujian sampel menggunakan NIRS (near infrared reflectance spectroscopy) sehingga didapatkan data kandungan bahan kering (BK), abu, protein kasar (PK), serat kasar (SK), serat diterjen netral (NDF), dan serat diterjen asam (ADF) pada pakan serat [15].

KcBK (Kecernaan bahan kering)

DMI (Konsumsi bahan kering)

RFV

Keterangan : KcBK
DMI

\section{Biaya Penyediaan Pakan Serat}

Kegiatan penyediaan pakan serat tentunya mengeluarkan biaya. Total biaya dapat dihitung menggunakan gabungan dari biaya variabel dan biaya tetap. Biaya variabel terdiri dari biaya pembelian pakan serat, tenaga kerja, biaya pemeliharaan lahan, dan biaya transportasi. Biaya tetap terdiri dari biaya sewa lahan, pajak lahan, biaya penyusutan dan perawatan peralatan yang digunakan dalam penyediaan pakan serat. Komponen biaya penyediaan pakan serat dijabarkan pada Tabel 1.

\section{Analisis Data}

Data yang didapatkan dianalisis secara deskriptif yang disajikan dalam bentuk tabel dan dokumentasi penelitian dengan maksud memberikan gambaran keadaan data.

\section{HASIL}

\section{Kondisi Umum Peternakan Sapi Perah di Lembang}

\section{Analisis Kualitas Pakan Serat}

Kualitas pakan dapat dibandingkan dengan perhitungan indeks nilai pakan relatif (RFV) [16]. Indeks tersebut dapat menentukan pakan yang paling baik digunakan sebagai pakan sumber serat. Penentuan indeks RFV dengan perhitungan sebagai berikut:

$=88,9-(0,779 \times \%$ ADF $)$

$=120 /(\% \mathrm{NDF})$

$=(\mathrm{KcBK} \times \mathrm{DMI}) / 1,29$

$=$ Kecernaan bahan kering

= Konsumsi bahan kering

Sistem pemeliharaan sapi perah di Kecamatan Lembang dilakukan secara intensif, dikandangkan sepanjang hari di belakang/samping rumah peternak. Dalam kegiatan pemerahan susu, beberapa peternak menggunakan mesin perah dan sisanya masih diperah manual.

Sistem pemberian pakan serat diberikan 2-3 kali/hari. Waktu pemberian pakan tersebut pada pagi dan sore hari sebelum ternak diberi konsentrat. Peternak yang mengarit hijauan hanya dilakukan pada pagi hari. Hijauan yang diarit habis dalam sehari. Sebagian besar peternak yang mengarit hijauan tidak menyetok hijauan untuk hari berikutnya. Peternak yang melakukan pembelian pakan serat seperti jerami padi akan disimpan lebih dari dua hari. Tidak ada tempat khusus dalam penyimpanan pakan, peternak biasanya menyimpan pakan serat di samping atau di depan kandangnya. Pada penyediaan pakan serat menggunakan transportasi manual atau kendaraan bermotor seperti sundung, gerobak, motor, dan mobil pick-up.

Tabel 1. Komponen biaya penyediaan pakan serat

\begin{tabular}{|c|c|c|c|c|c|}
\hline \multirow{2}{*}{ Komponen Biaya } & \multicolumn{5}{|c|}{ Cara penyediaan pakan serat dari } \\
\hline & Lahan sendiri & Lahan sewa & Lahan umum & Beli & Limbah \\
\hline \multicolumn{6}{|l|}{ Biaya Variabel } \\
\hline Biaya pakan & & & & $\sqrt{ }$ & \\
\hline Biaya tenaga kerja & $\sqrt{ }$ & $\sqrt{ }$ & $\sqrt{ }$ & $\sqrt{ }$ & $\sqrt{ }$ \\
\hline Biaya pemeliharaan lahan & $\sqrt{ }$ & $\sqrt{ }$ & & & \\
\hline Biaya transportasi & $\sqrt{ }$ & $\sqrt{ }$ & $\sqrt{ }$ & $\sqrt{ }$ & $\sqrt{ }$ \\
\hline \multicolumn{6}{|l|}{ Biaya Tetap } \\
\hline Biaya sewa lahan & & $\sqrt{ }$ & & & \\
\hline Pajak lahan & $\sqrt{ }$ & & & & \\
\hline Penyusutan peralatan & $\sqrt{ }$ & $\sqrt{ }$ & $\sqrt{ }$ & $\sqrt{ }$ & $\sqrt{ }$ \\
\hline Perawatan peralatan & $\sqrt{ }$ & $\sqrt{ }$ & $\sqrt{ }$ & $\sqrt{ }$ & $\sqrt{ }$ \\
\hline
\end{tabular}


Kegiatan Penyediaan Pakan Serat

Penyediaan pakan serat di peternakan Lembang dilakukan secara individu, berbeda dengan penyediaan konsentrat yang sudah dikoordinasikan oleh KPSBU. Tabel 2 menyajikan pola penyediaan pakan serat.

Tabel 2. Pola penyediaan pakan serat

\begin{tabular}{|c|c|c|c|c|}
\hline Pola & Cara Penyediaan & Sumber Pakan Serat & Biaya $(\mathrm{Rp} / \mathrm{kg})$ & Persentase Aktivitas (\%) \\
\hline \multirow[t]{2}{*}{1} & Lahan sendiri & Rumput gajah & $150,6 \pm 39,5$ & 6,0 \\
\hline & & Rumput lapang & $89,9 \pm 0,0$ & \\
\hline 3 & Lahan umum & Kaliandra & $522,3 \pm 0,0$ & 2,0 \\
\hline \multirow[t]{3}{*}{4} & Beli & Limbah brokoli & $777,8 \pm 0,0$ & 12,0 \\
\hline & & Jerami padi & $513,7 \pm 95,3$ & \\
\hline & & Rumput lapang & $777,8 \pm 0,0$ & \\
\hline \multirow[t]{2}{*}{1,2} & Lahan sendiri & Rumput gajah & $58,0 \pm 22,1$ & 4,0 \\
\hline & Lahan sewa & Rumput gajah & $229,3 \pm 170,4$ & \\
\hline \multirow[t]{4}{*}{1,4} & Lahan sendiri & Pelepah pisang & $93,2 \pm 0,0$ & 26,0 \\
\hline & & Rumput gajah & $187,9 \pm 103,8$ & \\
\hline & Beli & Jerami padi & $519,2 \pm 95,2$ & \\
\hline & & Limbah sayuran & $200,0 \pm 0,0$ & \\
\hline \multirow[t]{2}{*}{1,5} & Lahan sendiri & Rumput gajah & $173,9 \pm 0,0$ & 2,0 \\
\hline & Limbah & Jerami padi & $450,0 \pm 0,0$ & \\
\hline \multirow[t]{2}{*}{2,4} & Lahan sewa & Rumput gajah & $245,9 \pm 150,6$ & 4,0 \\
\hline & Beli & Jerami padi & $500,0 \pm 0,0$ & \\
\hline \multirow[t]{2}{*}{3,4} & Lahan umum & Rumput lapang & $258,9 \pm 236,8$ & 4,0 \\
\hline & Beli & Jerami padi & $683,3 \pm 23,6$ & \\
\hline \multirow[t]{2}{*}{3,5} & Lahan umum & Rumput Lapang & $238,2 \pm 0,0$ & 2,0 \\
\hline & Limbah & Jerami padi & $162,4 \pm 0,0$ & \\
\hline \multirow[t]{2}{*}{4,5} & Beli & Jerami padi & $325,0 \pm 0,0$ & 2,0 \\
\hline & Limbah & Jerami padi & $450,0 \pm 0,0$ & \\
\hline \multirow[t]{3}{*}{$1,2,4$} & Lahan sendiri & Rumput gajah & $139,4 \pm 89,3$ & 14,0 \\
\hline & Lahan sewa & Rumput gajah & $216,8 \pm 87,3$ & \\
\hline & Beli & Jerami padi & $516,6 \pm 116,8$ & \\
\hline \multirow[t]{4}{*}{$1,2,5$} & Lahan sendiri & Rumput gajah & $621,3 \pm 0,0$ & 2,0 \\
\hline & & Rumput lapang & $195,0 \pm 0,0$ & \\
\hline & Lahan sewa & Rumput gajah & $402,2 \pm 0,0$ & \\
\hline & Limbah & Jerami padi & $272,2 \pm 0,0$ & \\
\hline \multirow[t]{4}{*}{$1,3,4$} & Lahan sendiri & Rumput gajah & $256,5 \pm 134,6$ & 8,0 \\
\hline & Lahan umum & Rumput lapang & $356,6 \pm 54,3$ & \\
\hline & & Tumbuhan hutan & $340,0 \pm 0,0$ & \\
\hline & Beli & Jerami padi & $532,1 \pm 83,6$ & \\
\hline \multirow[t]{3}{*}{$2,3,4$} & Lahan sewa & Rumput gajah & $149,5 \pm 106,3$ & 4,0 \\
\hline & Lahan umum & Rumput lapang & $203,1 \pm 72,9$ & \\
\hline & Beli & Jerami padi & $500,0 \pm 0,0$ & \\
\hline \multirow[t]{4}{*}{$1,2,3,4$} & Lahan sendiri & Rumput gajah & $221,1 \pm 188,0$ & 4,0 \\
\hline & Lahan sewa & Rumput gajah & $504,7 \pm 323,4$ & \\
\hline & Lahan umum & Tumbuhan hutan & $470,6 \pm 67,4$ & \\
\hline & Beli & Jerami padi & $600,0 \pm 0,0$ & \\
\hline \multirow[t]{6}{*}{$1,3,4,5$} & Lahan sendiri & Rumput gajah & $178,7 \pm 120,3$ & 4,0 \\
\hline & Lahan umum & Daun pisang & $604,4 \pm 0,0$ & \\
\hline & & Tumbuhan hutan & $410,4 \pm 0,0$ & \\
\hline & Beli & Jerami padi & $600,0 \pm 0,0$ & \\
\hline & Limbah & Limbah sawi & $104,9 \pm 0,0$ & \\
\hline & & Kangkung & $576,0 \pm 0,0$ & \\
\hline
\end{tabular}

Keterangan : 1 = lahan sendiri, 2 = lahan sewa, 3 = lahan umum, $4=$ beli, $5=$ limbah 
Berdasarkan Tabel 2, terdapat 16 pola penyediaan pakan serat yang dilakukan di peternakan sapi perah Lembang. Pada musim kemarau, pola penyediaan pakan serat lebih banyak dibandingkan pada musim hujan.

Pola penyediaan yang paling banyak dilakukan adalah 1,4 (kombinasi mengarit di lahan sendiri dan membeli) dengan persentase 26,0\%; 4 (membeli) sebesar $12,0 \%$; dan 1,2,4 (kombinasi mengarit di lahan sendiri, mengarit di lahan sewa, dan membeli) sebesar $14,0 \%$. Tiga pola tersebut paling banyak dilakukan pada musim kemarau yang tentunya masing-masing pola terdapat kegiatan membeli jerami padi. Peternak memberikan rumput ataupun legum dalam bentuk segar. Hijauan tersebut sulit untuk disimpan lebih dari dua hari sehingga peternak harus kontinu mencari pakan serat tersebut. Jika peternak membeli jerami padi, pakan tersebut dapat disimpan lebih dari dua hari.

Biaya yang dibutuhkan dalam penyediaan pakan serat berbeda-beda walaupun dengan cara penyediaan yang sama. Seperti halnya cara penyediaan mengarit di lahan sendiri dan lahan sewa, penyediaan tersebut membutuhkan biaya budidaya hijauan.

\section{Sumber Pakan Serat}

Pakan serat yang digunakan di peternakan Lembang seluruhnya berasal dari lingkungan sekitar. Pakan serat yang diberikan kepada sapi perah di peternakan Lembang berupa rumput budidaya, tumbuhan alam, legum, dan limbah tanaman (limbah pertanian dan limbah sayuran). Sebagian besar peternak di Lembang tidak hanya memanfaatkan satu jenis saja, namun dapat dicampur dengan jenis pakan serat lainnya. Jenis pakan serat yang umumnya digunakan oleh peternak rakyat Lembang beserta kandungan nutrien dan jarak penyediaannya disajikan pada Tabel 3 .

Berdasarkan Tabel 3, komposisi nutrien pakan serat sangat bervariasi. Jerami padi memiliki kandungan BK paling tinggi karena kadar air jerami tentunya lebih rendah jika dibandingkan dengan pakan serat lainnya yang masih segar. Kandungan BK pakan serat seluruhnya berkisar 2,8 - 38,8 \%. Kandungan abu dari seluruh pakan serat berkisar 9,2 $28,1 \%$ BK.

Kandungan PK pakan serat antara 8,9 $31,0 \%$ BK. Legum dan limbah sayuran memiliki kandungan PK relatif tinggi. Jerami padi memiliki kandungan PK terendah diantara pakan serat lainnya. Kandungan PK pada jerami padi juga bervariasi. Sebagian besar peternak Lembang hanya menggunakan jerami padi sebagai pakan serat tambahan agar ternaknya merasa kenyang.

Peternak pada umumnya melakukan budidaya pakan serat yaitu rumput gajah. Rumput gajah yang dibudidayakan oleh peternak Lembang memiliki kandungan nutrien yang beragam.

Tumbuhan alam dan legum biasanya didapatkan oleh peternak yang melakukan penyediaan pakan dengan mengarit di lahan bukan miliknya.

Jarak penyediaan pakan serat $5-30.000$ meter dari peternakan. Jarak budidaya rumput yang dimiliki peternak bervariasi. Jarak penyediaan tumbuhan alam, legum, dan limbah tanaman juga beragam. Jarak penyediaan jerami padi memiliki jarak yang terendah sekaligus tertinggi.

Jenis pakan serat yang paling banyak digunakan di Lembang adalah rumput gajah sebesar $40,5 \%$. Jerami padi juga menjadi pakan serat yang banyak digunakan sebesar $33,6 \%$.

\section{Kualitas Pakan Serat}

Nilai kualitas pakan serat disajikan pada Tabel 4. Berdasarkan Tabel 4, pakan serat yang digunakan di peternakan Lembang memiliki komposisi NDF berkisar 20,0 - 60,7\% BK. Kandungan NDF pada legum dan limbah sayuran tergolong rendah.

Komposisi ADF dalam pakan serat berkisar 17,2 - 42,6\% BK. Jerami padi merupakan pakan serat yang memiliki komposisi ADF tertinggi.

Nilai RFV pada legum dan limbah sayuran seluruhnya memiliki nilai relatif tinggi. Limbah brokoli memiliki nilai RFV tertinggi sedangkan jerami padi memiliki nilai RFV terendah.

\section{Rantai Pasok}

Peta rantai pasok yang dibuat berdasarkan informasi yang diperoleh dari 
Tabel 3. Sumber pakan serat

\begin{tabular}{|c|c|c|c|c|c|c|}
\hline Pakan Serat & $\begin{array}{l}\text { BK } \\
(\%)\end{array}$ & $\begin{array}{c}\mathrm{Abu} \\
(\% \mathrm{BK})\end{array}$ & $\begin{array}{c}\text { PK } \\
(\% \mathrm{BK})\end{array}$ & $\begin{array}{c}\mathrm{SK} \\
(\% \mathrm{BK})\end{array}$ & $\begin{array}{c}\text { Jarak } \\
\text { penyediaan }(\mathrm{m}) \\
\end{array}$ & $\begin{array}{c}\text { Persentase } \\
(\%)\end{array}$ \\
\hline \multicolumn{7}{|l|}{ Rumput budidaya } \\
\hline $\begin{array}{l}\text { Rumput gajah } \\
\text { (Pennisetum purpureum) }\end{array}$ & $13,4 \pm 4,6$ & $14,6 \pm 2,7$ & $18,1 \pm 3,8$ & $30,0 \pm 2,9$ & $5-7.000$ & 40,5 \\
\hline \multicolumn{7}{|l|}{ Tumbuhan alam } \\
\hline $\begin{array}{l}\text { Aawian (lophatherum } \\
\text { gracile brogn) }\end{array}$ & $23,0 \pm 0,0$ & $9,2 \pm 0,3$ & $18,9 \pm 0,0$ & $31,0 \pm 0,1$ & 7.000 & 0,8 \\
\hline Sasawuhan & $14,3 \pm 0,0$ & $12,3 \pm 0,1$ & $17,5 \pm 0,1$ & $32,4 \pm 0,1$ & 100 & 0,8 \\
\hline $\begin{array}{l}\text { Kakawatan } \\
\text { (Cynodondactylon Pers.) }\end{array}$ & $34,8 \pm 0,0$ & $14,0 \pm 0,2$ & $24,2 \pm 0,0$ & $29,4 \pm 0,1$ & 1.000 & 0,8 \\
\hline Rumput lapang & $26,7 \pm 7,9$ & $14,5 \pm 4,1$ & $14,9 \pm 2,6$ & $29,9 \pm 3,6$ & $10-20.000$ & 8,4 \\
\hline $\begin{array}{l}\text { Campuran tumbuhan } \\
\text { hutan }\end{array}$ & $18,9 \pm 3,0$ & $10,5 \pm 0,9$ & $17,8 \pm 0,6$ & $21,9 \pm 3,9$ & $3.000-6.000$ & 3,0 \\
\hline \multicolumn{7}{|l|}{ Legum } \\
\hline Indigofera & $17,0 \pm 2,6$ & $11,7 \pm 0,0$ & $30,5 \pm 3,4$ & $19,9 \pm 3,6$ & $50-100$ & 0,8 \\
\hline Kaliandra & $27,3 \pm 5,1$ & $9,9 \pm 0,9$ & $27,3 \pm 6,4$ & $15,6 \pm 1,3$ & $100-3.000$ & 2,3 \\
\hline Baruntas & $11,5 \pm 0,4$ & $12,0 \pm 2,5$ & $28,7 \pm 0,6$ & $19,4 \pm 1,3$ & $100-1.000$ & 1,5 \\
\hline $\begin{array}{l}\text { Sintrong (Crassocephalum } \\
\text { crepidioides) }\end{array}$ & $7,9 \pm 0,0$ & $17,5 \pm 0,2$ & $25,0 \pm 0,1$ & $22,6 \pm 0,3$ & 1.000 & 0,8 \\
\hline Kania legum & $10,4 \pm 0,0$ & $12,4 \pm 0,3$ & $31,0 \pm 0,0$ & $17,0 \pm 0,2$ & 7.000 & 0,8 \\
\hline \multicolumn{7}{|l|}{ Limbah tanaman } \\
\hline Jerami padi & $38,8 \pm 8,7$ & $23,0 \pm 4,2$ & $8,9 \pm 2,3$ & $28,5 \pm 3,7$ & $5-30.000$ & 33,6 \\
\hline Daun pisang & $19,0 \pm 2,6$ & $12,1 \pm 2,5$ & $12,7 \pm 3,3$ & $33,3 \pm 2,2$ & 5.000 & 1,5 \\
\hline Pelepah pisang & $2,8 \pm 0,0$ & $28,1 \pm 0,1$ & $15,3 \pm 0,1$ & $24,9 \pm 0,1$ & 2.000 & 0,8 \\
\hline Limbah kangkung & $10,7 \pm 0,0$ & $14,1 \pm 0,1$ & $21,7 \pm 0,1$ & $17,3 \pm 0,1$ & 6.000 & 0,8 \\
\hline Limbah sawi & $7,3 \pm 0,2$ & $15,7 \pm 0,5$ & $30,2 \pm 1,0$ & $16,3 \pm 0,5$ & 10 & 0,8 \\
\hline Limbah brokoli & $15,0 \pm 5,1$ & $11,6 \pm 4,9$ & $27,7 \pm 4,2$ & $13,1 \pm 0,0$ & 5 & 1,5 \\
\hline $\begin{array}{l}\text { Campuran limbah } \\
\text { sayuran }\end{array}$ & $8,3 \pm 0,0$ & $10,5 \pm 0,1$ & $21,8 \pm 0,2$ & $15,2 \pm 0,2$ & 5 & 0,8 \\
\hline
\end{tabular}

observasi dan wawancara dengan peternak dan pelaku usaha pakan serat di Kecamatan Lembang. Peta rantai pasok pakan serat di peternakan Lembang disajikan pada Gambar 1.

Gambar 1 menunjukkan bahwa terdapat lima aliran pakan serat berdasarkan cara penyediaannya. Pakan serat umumnya digunakan dalam bentuk segar.

Pelaku dalam kegiatan pakan serat ini melibatkan 1-4 pelaku. Terdapat dua aliran yang berbeda pada rantai pasok hijauan (rumput dan legum). Pelaku yang terlibat dalam rantai pasok hijauan yaitu 1-2 pelaku. Hal ini karena beberapa peternak ada yang melakukan pengaritan sendiri dan ada juga yang membeli hijauan dalam penyediaannya. Rantai pasok jerami padi juga terdapat dua aliran yang berbeda, aliran ke 3 hanya melibatkan 2 pelaku saja yaitu petani dan peternak karena ada beberapa peternak yang langsung mencari jerami padi pada saat panen. Aliran ke 4 melibatkan pelaku yang paling banyak dibandingkan aliran pakan lainnya. Pelaku yang terlibat sebanyak 4 pelaku yaitu petani, pengepul 1 (bekerja sama dengan petani), pengepul 2 (melakukan penjualan jerami ke peternak), dan peternak. Sebagian besar pengepul 2 merupakan peternak yang melakukan kegiatan penyediaan pakan sekaligus melakukan kegiatan penjualan. Kegiatan ini dapat memberikan nilai tambah kepada peternak selain melakukan usaha peternakan sapi perah.

Alat transportasi yang digunakan dalam pengangkutan pakan serat menggunakan alat manual atau kendaraan bermotor. Peternak yang mengarit rumput di lahan terdekat dengan kandang, biasanya menggunakan alat 
Tabel 4. Nilai kualitas berbagai sumber pakan serat

\begin{tabular}{lccc}
\hline \multicolumn{1}{c}{ Pakan Serat } & NDF (\%BK) & ADF (\%BK) & RFV \\
\hline $\begin{array}{l}\text { Rumput budidaya } \\
\text { Rumput gajah (Pennisetum purpureum) }\end{array}$ & $53,5 \pm 8,3$ & $36,4 \pm 3,0$ & $109,0 \pm 27,0$ \\
$\quad$ Tumbuhan Alam & & \\
Aawian (lophatherum gracile brogn) & $60,7 \pm 0,2$ & $36,6 \pm 0,3$ & $92,6 \pm 0,0$ \\
Sasawuhan & $58,1 \pm 0,1$ & $37,4 \pm 0,1$ & $95,8 \pm 0,0$ \\
Kakawatan (Cynodondactylon Pers.) & $46,6 \pm 0,2$ & $31,3 \pm 0,3$ & $128,9 \pm 0,0$ \\
Rumput lapang & $53,8 \pm 6,0$ & $36,2 \pm 4,7$ & $106,8 \pm 41,7$ \\
Campuran tumbuhan hutan & $42,7 \pm 6,5$ & $32,7 \pm 4,6$ & $140,4 \pm 29,3$ \\
Legum & & & \\
Indigofera & $24,6 \pm 2,0$ & $22,8 \pm 2,2$ & $209,4 \pm 106,7$ \\
Kaliandra & $26,5 \pm 4,1$ & $21,4 \pm 3,0$ & $260,0 \pm 50,8$ \\
Baruntas & $35,1 \pm 7,8$ & $26,3 \pm 0,4$ & $185,9 \pm 40,6$ \\
Sintrong (Crassocephalum crepidioides) & $29,5 \pm 0,3$ & $25,4 \pm 0,4$ & $241,3 \pm 0,0$ \\
Kania legum & $29,0 \pm 0,2$ & $23,0 \pm 0,1$ & $227,9 \pm 0,0$ \\
Limbah tanaman & & & \\
Jerami padi & $57,4 \pm 4,9$ & $42,6 \pm 2,9$ & $91,3 \pm 11,6$ \\
Daun pisang & $56,0 \pm 1,1$ & $41,0 \pm 0,5$ & $94,7 \pm 1,3$ \\
Pelepah pisang & $37,5 \pm 0,1$ & $25,1 \pm 0,2$ & $221,7 \pm 0,0$ \\
Limbah kangkung & $23,8 \pm 0,2$ & $20,8 \pm 0,2$ & $315,0 \pm 0,0$ \\
Limbah sawi & $34,3 \pm 0,7$ & $28,7 \pm 0,9$ & $180,4 \pm 0,0$ \\
Limbah brokoli & $20,0 \pm 2,9$ & $17,2 \pm 1,4$ & $355,6 \pm 46,3$ \\
Campuran limbah sayuran & $30,4 \pm 0,4$ & $22,0 \pm 0,2$ & $219,3 \pm 0,0$ \\
\hline
\end{tabular}

pengangkutan yang terbuat dari kayu seperti sundung dan gerobak. Alat tersebut tidak membutuhkan bahan bakar gas, namun membutuhkan tenaga yang cukup dalam penggunannya. Jika jaraknya relatif jauh, alat transportasi yang digunakan umumnya menggunakan sepeda motor atau mobil pick-up. Tidak ada perlakuan khusus dalam pengangkutan pakan serat tersebut.

\section{PEMBAHASAN}

Lembang merupakan salah satu kecamatan di Kabupaten Bandung Barat yang menjadi wilayah pariwisata. Hal ini menunjukkan bahwa lahan untuk usaha peternakan dan budidaya hijauan di Lembang terbatas.

KPSBU (Koperasi Peternak Sapi Bandung Utara) merupakan salah satu koperasi yang membina sebagian besar peternak sapi perah di Kecamatan Lembang. Salah satu pelayanan yang diberikan KPSBU kepada peternak yaitu membantu penyediaan konsentrat, namun KPSBU tidak menyediakan pakan serat. Hal ini yang membuat peternak melakukan penyediaan pakan serat secara mandiri sehingga manajemen pemberian pakan serat pun berbeda-beda tiap peternakan.

Pemeliharaan ternak secara intensif memudahkan peternak dalam melakukan pekerjaannya karena peternak dapat mengerjakan pekerjaan lain dan tidak harus selalu mengawasi ternaknya sepanjang hari. Pemeliharaan tersebut juga lebih efektif dibandingkan menggembalakan ternak. Sistem pemeliharaan tersebut juga bertujuan untuk menghindari kehilangan ternak dan kerusakan yang tidak diinginkan [10].

Peternak memberikan pakan serat umumnya dalam bentuk segar, tidak diawetkan. Hal ini yang membuat peternak sangat menggantukan musim dalam kegiatan penyediaan pakan serat. Pada musim kemarau, peternak Lembang lebih banyak menggunakan jerami padi daripada rumput gajah/rumput lapang sebagai pakan serat, bahkan ada yang hanya memberikan jerami sebagai pakan serat dan juga memberikan pelepah pisang sebagai tambahan pakan serat lainnya.

Perbedaan pola pemberian pakan serat tiap usaha peternakan atau daerah dapat terjadi karena perbedaan ketersediaan 


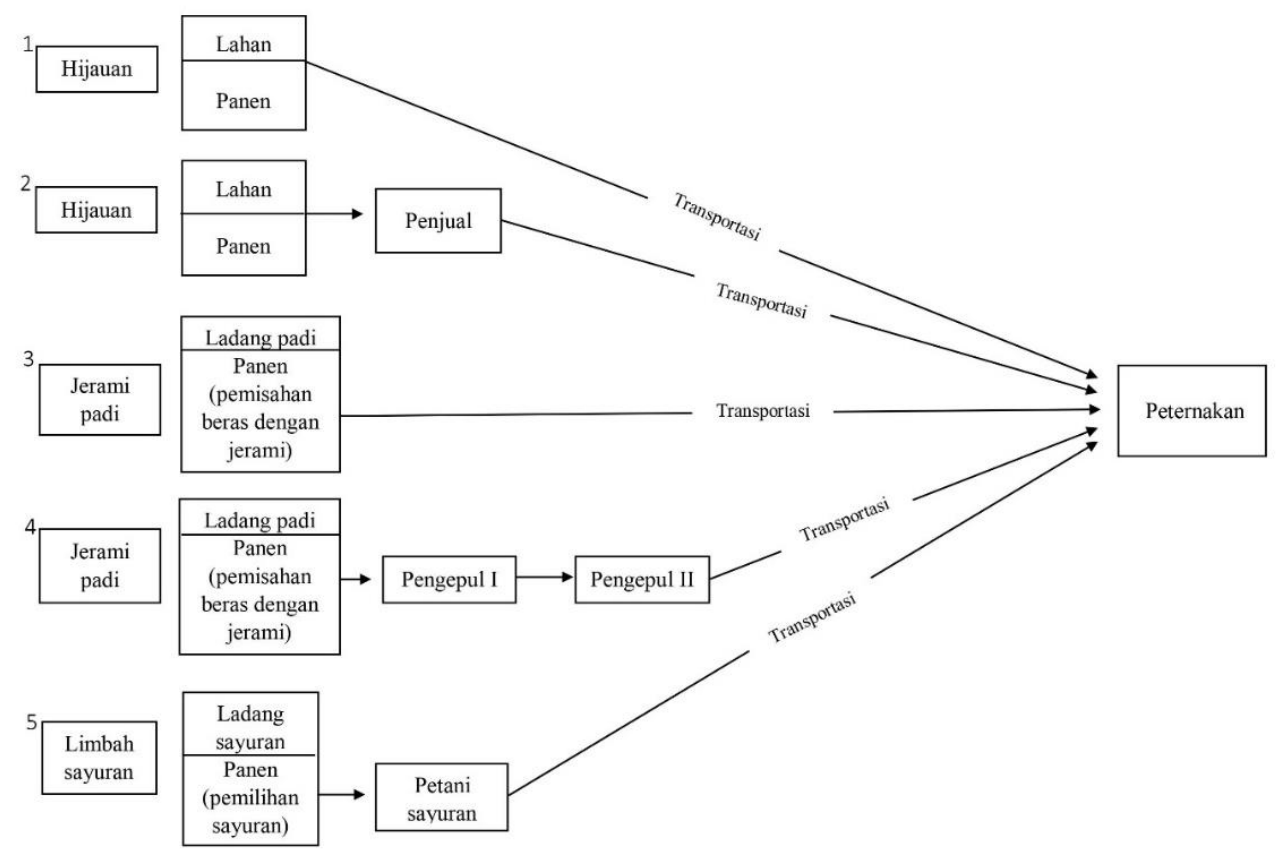

Gambar 1. Peta rantai pasok pakan serat

hijauan. Ketersediaan pakan serat seperti legum dan rumput sangatlah dipengaruhi oleh musim [17]. Lahan budidaya hijauan yang terbatas memungkinkan peternak melakukan kegiatan penyediaan pakan dengan membelinya. Pada musim hujan, sedikit sekali peternak melakukan pembelian pakan serat karena rumput dan legum pada musim tersebut tersedia cukup bahkan melimpah. Sebagian besar peternak melakukan pembelian pakan serat berupa jerami pada musim kemarau karena mudah didapat dan waktu simpannya relatif lebih lama dibandingkan pakan serat lainnya.

Peternak juga melakukan banyak cara dalam memperoleh pakan serat namun tetap merasa kekurangan dalam penyediaannya sehingga pemberian pakan serat tidak sebanyak pada musim hujan. Beberapa peternak ada yang melakukan penyediaan pakan serat tidak dipengaruhi oleh musim seperti mengarit di lahan sendiri dan mengarit di lahan umum. Beberapa budidaya hijauan di lahan milik sendiri tidak dipengaruhi oleh musim karena lahan tersebut berdekatan dengan kandang. Lahan tersebut selalu terairi oleh feses dan urin yang telah tercampur oleh air dari kandang ternak (limbah peternakan) sehingga hijauan tersebut tetap subur. Peternak yang tetap melakukan pengaritan pakan serat di lahan umum pada musim kemarau, waktu yang dibutuhkan menjadi lebih lama. Walaupun waktu yang dibutuhkan lebih lama, pakan serat yang diperoleh belum tentu cukup dalam penyediaannya. Hal ini sesuai dengan penelitian terdahulu yang menyatakan bahwa peternak pada musim kemarau melakukan banyak cara dalam persediaan hijauan agar tercukupi kebutuhan ternaknya. Dalam memperoleh pakan serat, peternak memerlukan biaya dan tenaga yang tidak sedikit untuk upaya tersebut [18].

Biaya budidaya hijauan di tiap peternak berbeda-beda tergantung penggunaan pupuk yang digunakan. Setiap daerah di Indonesia memiliki tingkat kesuburan tanah yang beragam. Keadaan tanah yang beragam dapat sebabkan oleh perbedaan perlakukan terhadap tanah di tiap daerah. Pemberian pupuk yang tidak benar dapat mengakibatkan kesuburan tanah menurun [19]. Perbedaan kesuburan tanah tersebut juga menghasilkan perbedaan produksi hijauan. Semakin tinggi jumlah produksi dalam kegiatan budidaya hijauan maka biaya pakan serat per kilogramnya akan semakin rendah.

Faktor lain yang mempengaruhi perbedaan harga pakan serat yaitu biaya tenaga kerja dan transportasi. Walaupun peternak sendiri yang melakukan kegiatan penyediaan ini, namun tanpa disadari 
tiap jamnya juga memerlukan tenaga yang dikeluarkan. Cara penyediaan mengarit di lahan umum biasanya membutuhkan biaya tenaga kerja yang lebih tinggi. Hal ini karena cara penyediaan tersebut biasanya memerlukan waktu yang lebih banyak untuk mencari lahan yang dapat dimanfaatkan sebagai sumber hijauan. Selain itu biaya transportasi juga berbeda-beda tiap peternak pada saat kegiatan penyediaan pakan. Jarak yang semakin jauh dan sedikit hijauan yang didapatkan akan memiliki biaya transportasi yang tinggi per kilogram hijuannya.

Berdasarkan Tabel 3, komposisi nutrien pakan serat sangat bervariasi. Jenis pakan serat yang sama pun dapat memiliki kandungan BK yang bervariasi. Variasi tersebut dapat diakibatkan dari ketersediaan air tanah yang menentukan bobot kering tanaman [9].

Pakan serat yang digunakan oleh peternak Lembang termasuk ke dalam pakan dengan sumber abu yang tinggi. Pakan yang memiliki kandungan abu diatas $8 \%$ BK dapat menjadi sumber mineral yang cukup untuk ternak [20].

Legum dan limbah sayuran memiliki kandungan protein yang tinggi. Pakan tersebut bisa sekaligus menyediakan kebutuhan protein harian untuk sapi perah di peternakan Lembang. Jerami padi memiliki kandungan PK terendah di antara pakan serat lainnya. PK pada jerami padi juga bervariasi. Jerami padi memiliki nilai gizi yang terbatas karena protein dan kecernaannya yang rendah sehingga tidak boleh digunakan sebagai pakan lengkap [21].

Rumput gajah yang dibudidayakan oleh peternak Lembang bermacam-macam varietasnya sehingga memiliki kandungan nutrien yang beragam. Bahkan jika memiliki varietas yang samapun, dapat beragam pula nilai nutrisinya. Kandungan PK rumput gajah di Lembang pada musim kemarau lebih tinggi dari pada rataan PK rumput gajah di Indonesia, namun kandungan PK rumput gajah dapat bervariasi yaitu $4,4 \%$ hingga $20,4 \%$ [22]. Rumput gajah, jerami padi, dan beberapa pakan serat lainnya yang memiliki kandungan nutrisi yang beragam dapat disebabkan oleh perbedaan waktu panen, jumlah dan kompoisisi pupuk yang digunakan, kondisi tanah, dan umur tanaman itu sendiri. Faktor dalam penentuan waktu panen yang tepat yaitu kematangan hijauan itu sendiri. Saat hijauan semakin dewasa, nilai gizinya akan menurun seperti penurunan protein dan kecernaannya [23].

Kandungan nutrien dalam rumput lapang dan tumbuhan hutan tergantung dari jenis pakan serat yang terdapat di dalamnya. Rumput lapang dan tumbuhan hutan merupakan gabungan jenis pakan serat yang berbeda karena setiap ladang rumput terdapat campuran jenis tumbuhan yang berbeda dalam kualitasnya sehingga sulit untuk menentukan nilai gizinya [24].

Beberapa peternak memiliki lahan budidaya rumput dekat kandangnya, namun tidak sedikit peternak yang lahannya jauh dari peternakan. Hal tersebut yang membuat arak budidaya rumput bervariasi. Jarak penyediaan tumbuhan alam, legum, dan limbah tanaman juga beragam karena peternak tidak hanya mencari di satu tempat saja, setiap harinya dapat berpindahpindah tempat sesuai ketersediaan pakan tersebut. Jarak penyediaan jerami padi memiliki jarak yang terendah sekaligus tertinggi. Hal ini karena beberapa peternak melakukan pembelian jerami sekaligus diberikan pelayanan pengantaran jerami hingga sampai ke peternakan. Peternak yang membeli jerami, hanya mengambil jerami tersebut berjarak $5-10$ meter dari kandangnya. Berbeda dengan peternak yang mencari jerami sendiri, jarak terjauh sekitar 30.000 meter dari kandang.

Rumput gajah menjadi pakan serat yang paling banyak digunakan di Lembang. Rumput gajah sangat potensial dibudidayakan di daerah tersebut sehingga menjadi pakan serat utama untuk ternak ruminansia. Rumput gajah merupakan hijauan dengan produktivitas dan kualitas yang tinggi. Rumput tersebut mudah dibudidayakan di daerah tropis dengan biaya produksi yang relatif rendah dan biasanya digunakan sebagai pakan ternak ruminansia [25].

Jerami padi juga menjadi pakan serat yang banyak dimanfaatkan oleh peternak Lembang. Padahal tidak sedikit 
peternak mengetahui kandungan protein dan kecernaannya rendah, jerami juga kurang disukai oleh ternak. Peternak tetap memanfaatkan limbah tersebut sebagai pakan sumber serat karena peternak mudah mendapatkan jerami tanpa bergantung musim. Pakan serat tersebut digunakan peternak sebagai alternatif campuran/ pengganti hijuan. Selain jerami padi, peternak juga memanfaat limbah pertanian lain sebagai pakan serat. Limbah pertanian dapat digunakan oleh ruminansia secara efisien seperti halnya produk samping pabrik [20]. Limbah sayuran dapat menjadi sumber pakan serat dengan nilai gizi yang baik. Hal ini menunjukkan adanya pemanfaatan limbah pertanian sebagai pemenuhan pakan serat yang berkelanjutan. Pemanfaatan jerami padi dan limbah sayuran dapat membantu efisiensi terkait pembuangan produk pertanian yang berpotensi masih memiliki nutrisi untuk dijadikan pakan ternak ruminansia [26].

Kandungan NDF pada legum dan limbah sayuran tergolong rendah. Hal ini karena kandungan serat yang terkandung di dalamnya lebih sedikit dan kecernaannya lebih tinggi untuk ternak jika dibandingkan dengan pakan serat lainnya. NDF dan ADF rumput memang lebih tinggi dibandingkan legum. Kecernaan legum yang tinggi juga dapat dikaitkan dengan struktur dan bentuk daun. Proporsi batang yang lebih tinggi dalam rumput mengakibatkan kandungan serat yang tinggi [24].

Beberapa pakan serat memiliki kandungan ADF yang bervariasi. Variasi ini dapat disebabkan perbedaan umur jenis pakan serat pada saat panen [20]. Jerami padi merupakan pakan serat yang memiliki komposisi ADF tertinggi. Tingginya kandungan ADF pada pakan menunjukkan tingkat kecernaan bahan kering rendah [23]. Pakan yang memiliki kandungan ADF yang rendah cenderung lebih mudah dicerna oleh ternak [21]. Hal ini karena lignin terkandung dalam ADF.

Nilai RFV menggambarkan kualitas hijauan, semakin tinggi nilai RFV menunjukkan hijauan memiliki kualitas yang semakin tinggi [27]. Nilai RFV pada legum dan limbah sayuran seluruhnya memiliki nilai relatif tinggi sehingga menunjukkan bahwa pakan tersebut sangat baik digunakan sebagai pakan serat. Limbah brokoli memiliki nilai RFV tertinggi pada pakan serat di Lembang. Pakan serat tersebut memiliki kualitas yang paling baik di antara pakan serat lainnya. Kualitas terendah pakan serat dimiliki oleh jerami padi karena mengandung nilai ADF tertinggi. RFV juga ditentukan dari kandungan NDF dan ADF dalam pakan. Semakin rendahnya nilai ADF akan meningkatkan nilai RFV pada pakan serat.

Rantai pasok pakan serat pada aliran 1,2, dan 5 memiliki rantai yang pendek sedangkan aliran 3 dan 4 memiliki rantai menengah. Bahan baku pakan tanpa diolah, tidak ada penyimpanan, dan transportasi yang digunakan manual serta jarak dari titik sumber ke destinasi berkirsar 200-500 meter memiliki rantai yang pendek. Rantai menengah pada pakan biasanya terdapat kegiatan proses seperti pemisahan atau pengupasan sehingga menghasilkan limbah pertanian serta transportasi yang digunakan biasanya menggunakan kendaraan bermotor dan jarak dari titik sumber ke destinasi berkisar 1-5 kilometer [28].

Rantai pasok pakan serat lebih pendek jika dibandingkan dengan pakan komplit (konsentrat) yang memang harus diolah terlebih dahulu. Produk yang diperoleh/ dijual dalam bentuk segar maupun tanpa diolah biasanya memiliki rantai pasok yang pendek. Hal ini untuk menghindari adanya penambahan akibat kerusakan produk dalam jumlah yang besar [29].

Pastinya dalam kegiatan rantai pasok terdapat beberapa kendala. Kendala dalam aliran tersebut yaitu sarana dan biaya transportasi. Alat transportasi yang digunakan dalam pengangkutan pakan serat menggunakan alat transportasi manual dan kendaraan bermotor. Peternak yang mengarit rumput di lahan terdekat dengan kandang, biasanya menggunakan alat pengangkutan yang terbuat dari kayu seperti sundung dan gerobak. Alat tersebut tidak membutuhkan bahan bakar gas, namun membutuhkan tenaga yang cukup dalam penggunannya. Jika jaraknya relatif jauh, alat transportasi yang digunakan 
umumnya menggunakan sepeda motor atau mobil pick-up. Tidak ada perlakuan khusus dalam pengangkutan pakan serat tersebut. Sebagian besar peternakan rakyat ruminansia di Indonesia biasanya menggunakan pikulan, sepeda atau gerobak untuk mengangkut pakan serat sampai ke kandang [10].

Kendala lain dalam aktivitas rantai pasok tersebut yaitu peternak yang mencari hijauan di lahan umum atau mencari limbah pertanian masih belum mengetahui lokasi yang tepat dalam memperoleh pakan tersebut. Mereka memerlukan waktu untuk mencari lahan yang dapat dimanfaatkan sebagai sumber pakan serat. Bahkan peternak dapat membutuhkan waktu 1-3 jam dalam mencari lahan tersebut. Hal ini yang membuat kegiatan tersebut tidak efisien dari segi waktu, tenaga, maupun biaya transportasi.

Berbeda dengan industri konsentrat yang sudah menerapkan manajemen rantai pasok, kegiatan dalam rantai pasok pakan serat belum menerapkan manajemen tersebut. Hal ini karena peternak melakukan penyediaan pakan serat secara individu. Jika peternak melakukan kegiatan tersebut terkoordinasi, memungkinkan manajemen rantai pasok diterapkan. Hal ini memungkinkan peternak lebih mudah melakukan penyediaan pakan serat sehingga mereka lebih dapat fokus terhadap pemeliharaan ternak mereka. Penerapan manajemen rantai pasok sangatlah penting. Penerapan tersebut dapat memberikan dampak yang signifikan terhadap biaya produksi hasil ternak. Perubahan pada pola produksi hijauan merupakan salah satu perbaikan untuk memfasilitasi rantai pasok pakan [13]. Rantai pasok yang lebih baik akan mendorong pertumbuhan produk ternak [30].

\section{KESIMPULAN}

Kegiatan penyediaan pakan serat yang dilakukan di peternakan rakyat sapi perah Lembang terdapat 16 pola penyediaan pada musim kemarau. Pola penyediaan pakan serat yang paling banyak dilakukan pada musim tersebut yaitu kombinasi mengarit di lahan sendiri dan membeli. Biaya penyediaan pakan serat berbeda-beda bukan berdasarkan cara penyediaannya, namun tergantung dari biaya variabel dan tetap yang dikeluarkan pada kegiatan tersebut. Pakan serat yang digunakan di peternakan tersebut berupa rumput budidaya, tumbuhan alam, legum, dan limbah tanaman yang seluruhnya berasal dari daerah sekitar dengan kandungan nutrien dan jarak penyediaan yang bervariasi. Berdasarkan perhitungan RFV, legum dan limbah sayuran memiliki kualitas yang tinggi dan sangat baik digunakan sebagai pakan serat sedangkan jerami padi tidak disarankan sebagai pakan tersebut. Rantai pasok pakan serat memiliki rantai pendek dan menengah karena pakan serat yang digunakan umumnya dalam bentuk segar dan tanpa diolah.

\section{KONFLIK KEPENTINGAN}

Penulis menyatakan tidak terdapat konflik kepentingan dengan pihak manapun terkait materi yang ditulis dalam naskah ini.

\section{UCAPAN TERIMA KASIH}

Penulis mengucapkan terima kasih kepada KPSBU dan para peternak sapi perah di Kecamatan Lembang yang telah mengizinkan pelaksanaan wawancara dan pengambilan sampel sebagai data dalam penelitian ini.

\section{REFERENSI}

1. Martin, N. P., M. P. Russelle, J. M. Powell, Sniffen, S. I. Smith, J. M. Tricarico, and R. J. Gran. 2017. Invited review: sustainable forage and grain crop production for the US dairy industry. J. Dairy Sci. 100(12):9479-9494. Doi: 10.3168/jds.201713080.

2. Melesse, A., H. Steingass, M. Schollenberger, and M. Rodehutscord. 2017. Screening of common tropical grass and legume forages in Ethiopia for their nutrient composition and methane production profile in vitro. Trop. Grassl.Forrajes Trop. 5(3):163-175. Doi: 10.17138/ tgft(5)163-175. 
3. Yanti, Y., and M. Yayota. 2017. Agricultural by-products as feed for ruminants in tropical area: nutritive value and mitigating methane emission. Reviews Agric. Sci. 5:65-76. Doi: 10.7831/ras.5.65.

4. Yang, W. Z., and K. A. Beauchemin. 2006. Effects of physically effective fiber on chewing activity and ruminal $\mathrm{pH}$ dairy cows fed diets based on barley silage. J. Dairy Sci. 89(1):217-228. Doi: 10.3168/ jds.S0022-0302(06)72086-0.

5. Srivastava, S., V. Mudgal. and R. K. Jain. 2012. Lignin - its role and importance in animal nutrition. Int. J. Livest. Res. 2(1):724.

6. Novianti, J., B. P. Purwanto, and A. Atabani. 2013. Respon fisiologis dan produksi susu sapi perah FH pada pemberian rumput gajah (Pennisetum Purpureum) dengan ukuran pemotongan yang berbeda. J. I. P. T. P. 1(3):138-146.

7. Despal, J. Malyadi, Y. Destianingsih, A. Lestari, H. Hartono, and L. Abdullah. 2014. Natural grass and plant residue qualities and values to support lactating cows requirement on forage at indonesian small scale enterprise and traditional dairy farming. Proc. Int. Workshop Trop. Bioresources for Sustainable Dev. IPB Press, Bogor, ID.

8. Santosa, S. I., A. Setiadi, and R. Wulandari. 2013. Analisis potensi pengembangan usaha peternakan sapi perah dengan menggunakan paradigm agribisnis di Kecamatan Musuk Kabupaten Boyolali. Buletin Peternakan. 37(2):125-135. Doi: 10.21059/buletinpeternak.v37i2.2431.

9. Mufarihin, A., D. R. Lukiwati, and Sutarno. 2012. Pertumbuhan dan bobot bahan kering rumput gajah dan rumput raja pada perlakuan aras auksin yang berbeda. Anim. Agric. J. 1(2):1-15.

10. Ningsih, A. S., and A. Setiana. 2011. Pola penyediaan hijauan pakan ternak ruminansia kecil di Desa Pantai Sidoharjo, Kecamatan Pacitan, Kabupaten Pacitan. Agromedia. 29(1):1-6.

11. Sutaryono, Y. A. 2008. Forage resources in livestock-cropping smallholder systems. a case study of farmers at transmigration areas of Dompu, West Nusa Tenggara. Media Peternakan. 31(2):146-154.
12. Janvier-James, A. M. 2012. A new introduction to supply chains and supply chain management: definitions and theories perspective. Int. Bus. Res. 5(1):194207. Doi:10.5539/ibr.v5n1p194.

13. Deppermann, A., P. Havlík, H. Valin, E. Boere, M. Herrero, J. Vervoort, and E. Mathijs. 2018. The market impacts of shortening feed supply chains in Europe. Food Security. 10:1401-1410. Doi: 10.1007/s12571-018-0868-2.

14. Dolores, M. and C. Tongco. 2007. Purposive sampling as a tool for informant selection. Ethnobotany Research and Aplications. 5: 147-158.

15. Despal, L. A. Sari, R. Chandra, R. Zahera, I. G. Permana and L. Abdullah. 2020. Prediction accuracy improvement of Indonesian dairy cattle fiber feed compositions using near-infrared reflectance spectroscopy local database. Trop. Anim. Sci. J. 43(3):263-269. Doi: 10.5398/tasj.2020.43.3.263.

16. Dunham, J. R. 1998. Relative feed value measures forage quality. Forage Facts. KState AES, Kansas, US.

17. Meena, G. L., H. S. Besarwai, and H. Sharma. 2013. Pattern of dairy input procurement, output disposal and feeding in Tribal Region of Udaipur District of Rajasthan. Ind. J. Extn. Educ. R. D. 21:125130.

18. Handayanta, E., E. T. Rahayu, and M. A. Wibowo. 2015. Aksesibilitas sumber pakan ternak ruminansia pada musim kemarau di daerah pertania lahan kering. Sains Peternakan. 13(2):105-112.

19. Lasamadi, R. D., S. S. Malalantang, Rustandi, and S. D. Anis. 2013. Pertumbuhan dan perkembangan rumput gajah dwarf (Pennisetum purpureum cv. Mott) yang diberi pupuk organik hasil fermentasi EM4. J. Zootek. 32(5):158-171.

20. Pavithra, S., J. K. Vidanarachchi, M. Sarmini, and S. Premaratne. 2019. Chemical composition and gross energy content of commonly available animal feedstuff in Sri Lanka. J. Natn. Sci. Foundation Sri Langka. 47(1):79-87. Doi: 10.4038/jnsfsr.v47il.8925.

21. Drake, D. J., G. Nader, and L. Forero. 2002. Feeding rice straw to cattle. ANR 
Publication 8079. 1-17. ISBN 978-1-601072559.

22. Rusdy, M. 2016. Elephant grass as forage for ruminant animals. L. R. R. D. 28(4):1-6.

23. Bohnert, D., D. Chamberlain, S. Filley, R. Hathaway, J. Males, B. Nisley, J. Oldfield, C. Parsons, R. Pawelek, G. Pirelli, M. Porath, and P. Schreder. 2004. Beef cattle nutrition workbook. Oregon State University, Oregon, US.

24. Amiri, F., A. Rashib, and M. Shariff. 2012. Comparison of nutritive values of grasses and legume species using forage quality index. Songklanakarin J. Sci. Tech.. 34(5): 577-586.

25. Vidal, A. K. F., T. C. Barbe, R. F. Daher, J. E. A. Filho, R. S. N. Lima, R. S. Freitas, D. A. Rossi, E. S. Oliveira, B. R. S. Menezes, G. C. Entringer, W. F. S. Peixoto, and S. Cassaro. 2017. Production potential and chemical compotition of elephant grass (Pennisetum purpureum Schum.) at different ages for energy purposes. Afr. J. Biotechnol. 16(25): 1428-1433. Doi: 10.5897 /ajb2017.160 14 .
26. Wyngaarden, S. L., K. K. Lightburn, and R. C. Martin. 2019. Optimizing livestock feed provision to improve the efficiency of the agri-food system. Agroecology and Sustainable Food Systems. 44(2):188-214. Doi: 10.1080/2168 3565.2019.1633455.

27. Jacek, S., J. Kazimierz, D. Piotr, H. Dorota, K. Justyna, and M. Alex. 2015. Relative feed value of different varieties of Dactylis glomerata and Festuca pratensis. J. Life Sci. 9:443-448. Doi: 10.17265/1934-7391/2015.09. 006.

28. FAO. 2016. Environmental performance of animal feeds supply chains: guidelines for assessment. FAO, Roma, IT.

29. Imanullah, M. N. 2017. Petani dalam perdagangan pangan internasional. Penerbit Pustaka Hanif, Surakarta, ID.

30.Samboko, P. C., O. Zulu-Mbata, and A. Chapoto. 2018. Analysis of the animal feed to poultry value chain in Zambia. Dev. Southern Africa. 35(3):351-368. Doi: /10.1080/0376835x.2018.1480932. 